
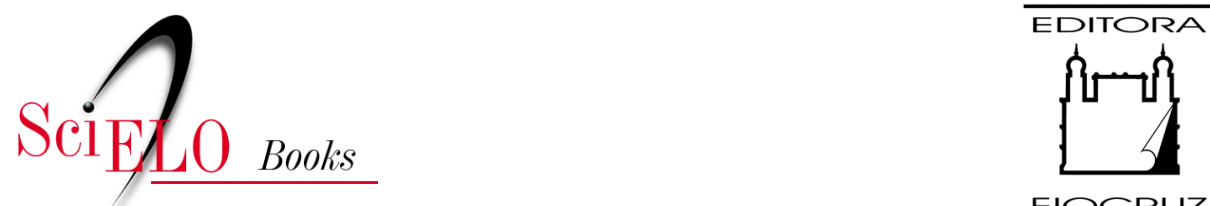

FIOCRUZ

\title{
Prólogo à segunda edição
}

\author{
Flavío Coelho Edler
}

\section{SciELO Books / SciELO Livros / SciELO Libros}

EDLER, F. C. Prólogo à segunda edição. In: FRAGA, C. Vida e Obra de Oswaldo Cruz [online]. 2nd ed. Rio de Janeiro: Editora FIOCRUZ, 2005, pp. 11-13. ISBN: 978-65-5708-099-3. https://doi.org/10.7476/9786557080993.0002.

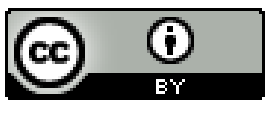

All the contents of this work, except where otherwise noted, is licensed under a Creative Commons Attribution 4.0 International license.

Todo o conteúdo deste trabalho, exceto quando houver ressalva, é publicado sob a licença Creative Commons Atribição 4.0.

Todo el contenido de esta obra, excepto donde se indique lo contrario, está bajo licencia de la licencia Creative Commons Reconocimento 4.0. 


\section{PRÓLOGO À SEGUNDA EDIÇÃO}

bibliografia sobre oswaldo Cruz é composta por dezenas de necrológios, arti-
gos de feição histórica, biocronologias, biografias e até mesmo uma revista de história em quadrinhos que narra a campanha de saneamento do Rio de Janeiro, no início do século XX. Nessa literatura constata-se a repetição exaustiva de símbolos, imagens, fatos e versões reveladores de um processo que, em alguns casos, levou à sua mitificação e canonização. A construção da biografia mítica do 'criador de Manguinhos' iniciou-se logo após sua morte, em fevereiro de 1917. Mitos, obviamente, năo se constroem no vazio. Como observou Nara Azevedo, ${ }^{1}$ médicos e hìgienistas transformaram-se em cultores de sua memória, em parte porque perceberam que a grande lacuna deixada pelo 'saneador do Rio de Janeiro' podia ser convertida num legado simbólico, capaz de mobilizar os seus contemporâneos em prol de determinadas causas. Essa hagiografia visava, em parte, a legitimar o movimento sanitarista, organizado em torno da Liga Pró-Saneamento do Brasil, e, ao mesmo tempo, pacificar as desavenças internas ao Instituto Oswaldo Cruz. A identificação do 'fundador da medicina experimental no Brasil' com os valores do progresso, da saúde pública e da ciência, cultivados pela elíte política republicana, e sua conversão em apóstolo e mártir da ciência brasileira ajudaram tanto a legitimação sociaI quanto a formação do consenso necessário para a ação política de duas espécies, entăo recém-aclimatadas ao nosso solo: o sanitarista e o cientista.

\footnotetext{
${ }^{1}$ BRITTO, N. Oswaldo Cruz: a construçāo de um mito na ciência brasileira. Rio de Janeiro: Ed. Fiocruz, 1995.
} 
A maioria desses escritos, apesar de seu valor literário e histórico, perdeu muito de sua força evocativa. O estilo grandiloqüente e as figuras de linguagem, próprias daquele gênero epidíctico, já não mais conseguem mobilizar os sentimentos do leitor moderno. Já Pedro Nava, um de nossos maiores memorialistas, reclamava da parcialidade das biografias da maioria dos nossos grandes médicos e do tratamento "com luvas de borracha que desinfetam tudo que existe de humano para só ensaiar o mito esterilizado que anula o homem. Onde estais, Miguel Couto, Oswaldo Cruz e Carlos Chagas? Quem vos poderá conhecer dentro de roupas de santo com que vos afublaram e que tanto vos desfiguram? Esquecem que cada homem só vive e é grande quando mostrado integralmente. Nos seus erros e acertos. Nos acertos e erros dos outros sobre sua pessoa". ${ }^{2}$

Por outro lado, quando, a partir de meados da década de 1970, historiadores e cientistas sociais voltaram seus interesses para o estudo histórico da trajetória institucional da ciência brasileira e para as temáticas da saúde pública, rejeitaram como ingênuas as narrativas centradas na ação dos protagonistas e deslocaram a abordagem para as redes de relaçōes sociais e econômicas que determinariam as ações dos sanitaristas naquela conjuntura histórica. A intenção era explicitar os mecanismos sociológicos subjacentes e revelar a forma pela qual os interesses econômicos das elites republicanas - empenhadas em encontrar uma solução definitiva para os problemas sanitários que ameaçavam os lucros da lavoura cafeeira - puderam galvanizar as ações dos médicos-cientistas no intuito de institucionalizar a pesquisa biomédica no campo da saúde pública. ${ }^{3}$

Vida e Obra de Osvaldo Cruz, escrita por Clementino Fraga, encontra-se a meio-termo entre o mito e sua negação. Seu autor revela-se um cultor exigente da memória de seu biografado. Porquanto haja sobejas evidências de admiração

\footnotetext{
${ }^{2}$ NAVA, R. Baú de Ossos. 7.ed. Rio de Janeiro: Nova Fronteira, 1984. p. 251.

${ }^{3}$ Entre os trabalhos mais marcantes que caracterizam esse tipo de abordagem, destaco, em ordem cronológica: STEPAN, N. Gênese e Evoluçäo da Ciência Brasileira: Oswaldo Cruz e a política de investigaçāo cientifica e médica. Rio de Janeiro: Artenova, 1976; LUZ, M. T. Medicina e Ordem Política Brasileira: políticas e instituiçóes de saúde (1850-1930). Rio de Janeiro: Graal, 1982; CASTRO-SANTOS, L. A. de. O pensamento sanitarista na Primeira República: uma ideologia de construçāo de nacionalidade. Dados - Revista de Ciências Sociais, 28(2):193-210, 1985; BENCHIMOL, J. L. Manguinhos do Sonho à Vida: a ciência na Belle Époque. Rio de Janeiro: Casa de Oswaldo Cruz/Fiocruz, 1990; HOCHMAN, G. A Era do Saneamento: as fases da politica de saúde pública no Brasil. Sāo Paulo: Hucitec, Anpocs, 1998.
} 
e afeto, além de coincidências biográficas que projetam, na interpretação de Oswaldo Cruz, elementos da personalidade do próprio autor, a sobriedade da linguagem e o recurso aos documentos de época combinam-se na produção de uma obra empolgante e objetiva.

A excelente iniciativa de sua reedição, pela Editora Fiocruz, passadas três décadas desde sua primeira e única edição pela Livraria José Olympio Editora, ${ }^{4}$ encontrará larga ressonância entre o público que tem se mostrado ávido pelo gênero. O crescente interesse pelas biografias vem preenchendo, de certa forma, as perdas de referências ideológicas, um dos traços do cenário cultural contemporâneo. Por outro lado, a crise dos enfoques excessivamente centrados na identificação das estruturas e na ação das massas e atores coletivos, independentemente das opçōes e intençōes dos indivíduos, tem aproximado os historiadores das categorias e do léxico dos atores, conduzindo suas atençōes para os indivíduos e suas redes de interaçōes, nas quais se desenham laços de solidariedade e antagonismos.

Patrimônio simbólico disputado e reverenciado pela medicina e ciência brasileiras, a memória sempre lembrada e celebrada de Oswaldo Cruz encontra nesta composição sua mais bem acabada reconstruçāo.

Flavio Coelho Edler Historiador, pesquisador da Casa de Oswaldo Cruz (COC/Fiocruz)

4 Para efeitos desta segunda ediçāo, foram mantidas as características da primeira, até mesmo a grafia original 